\title{
Canine Thyroid Adenocarcinoma
}

National Cancer Institute

\section{Source}

National Cancer Institute. Canine Thyroid Adenocarcinoma. NCI Thesaurus. Code C132275.

Adeonocarcinoma of the thyroid gland occurring in a dog. 